\title{
Биография номера
}

\section{Алкоголь и опыт выстраивания идентичности: анализ биографического интервью}

\section{DOI: 10.19181/inter.2021.13.3.6}

Ссылка для цитирования:

Котельников М. П. Алкоголь и опыт выстраивания идентичности: «биографическое интервью» // Интеракция. Интервью. Интерпретация. 2021. Т. 13. № 3. С. 130-145. DOI: https://doi. org/10.19181/inter.2021.13.3.6

\section{For citation:}

Kotelnikov M.P. (2021) Alcohol and the Identity-Building Experience: The Biographical Interview. Interaction. Interview. Interpretation. Vol. 13. No. 3. P. 130-145. DOI: https://doi.org/10.19181/ inter.2021.13.3.6

$\|$

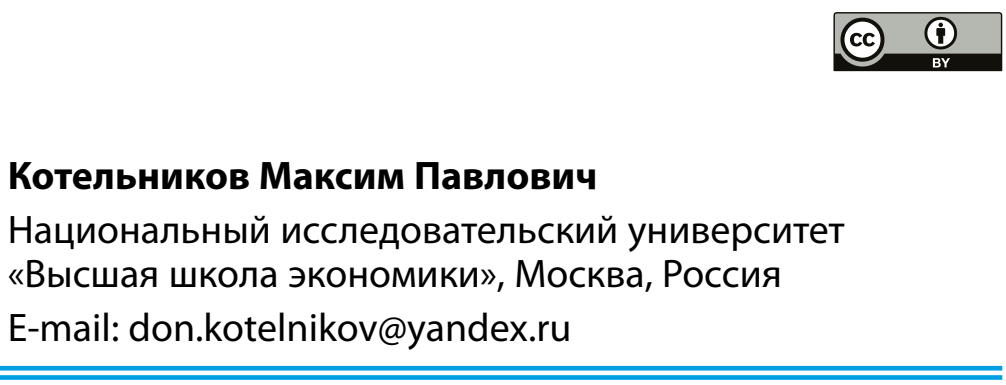

В рамках данной работы автор исследует индивидуальные «стратегии» распития спиртного и их связь с социальным контекстом. Для реализации этой задачи используется концепчия «режимов вовлеченности» Лорана Тевено. На основании глубинного биографического интервью выделяются три этапа употребления алкоголя, через которые прошла (или проходит) информантка, молодая девушка среднего класса: 1) подростковый период: «игра», суть которой сводится к сокрытию факта распития алкоголя от родителей; 2) студенческий период (жизнь в общежитии): стратегия употребления уподобляется "режиму открытия» по Тевено, отличительной особенностью которого является поиск нового - именно на этом этапе информантка начинает активно употреблять крепкие напитки и всячески исследовать «алкогольный мир», в это время благодаря тяге к открытиям она заводит близких друзей; 3) настоящее время (жизнь в одиночестве): нерефлексивное рутинное употребление алкоголя - такая стратегия определяется в соответствии с «режимом близости» по Тевено, характеризуюшимся возрастанием значимости того или иного объекта (в данном случае алкоголя), однако вместе с тем актор теряет возможность рефлексировать о своих отношениях с объектом в силу того, что он становится частью его «невопрошаемой» повседневности. Также в статье рассматриваются 
модели концептуализации алкоголя и алкоголизма, используемые самой информанткой.

Ключевые слова: режим вовлеченности; алкоголь; алкоголизм; стигма; биография; игра

\section{Введение. Алкоголь в социальных науках}

Алкоголь как предмет исследования в социологии концептуализировался преимущественно в качестве средства, «помогающего» определенным группам, как правило, сталкивающимся с различными социальными проблемами, будь то бедность, отчуждение и т.д., снизить уровень тревожности и в той или иной мере принимать непростые жизненные условия [Seeman et al., 1988]. Впрочем, подчеркивалось, что никакой «действительной» помощи алкоголь не оказывает: на короткой дистанции спиртное действительно может улучшить самочувствие, однако на длинной приводит лишь к более серьезным проблемам для пьющего. Конечно, это не значит, что для социальных ученых «позитивные» функции алкоголя всегда оставались в слепой зоне. Существует ряд работ, показывающих, что обильное употребление спиртного может быть интегрировано в различные социальные практики и вовсе не обязательно связано с маргинальным статусом пьющих [Heath, 1987; Mulford, Miller, 1961]. Однако в целом в публикациях большинства социологов прослеживается некая морализаторская тенденция, следуя которой, ученые говорят преимущественно об опасности употребления алкоголя как для пьющего, так и для общества в целом. В российском социологическом пространстве интересным исключением является работа Михаила Соколова «Пьянка: Исследование социального производства опыта не-идентичности» [Соколов, 2005]. Это преимущественно теоретический текст, хотя в нем немало любопытных отсылок к личному опыту автора, а также обыденных (но полезных) интуиций. Основной тезис Соколова заключается в том, что чрезмерное употребление алкоголя может приводить к тому, что актор «узнает себя с другой стороны», что, в свою очередь, обогащает его опыт восприятия себя: «Вне зависимости от того, нравится нам или нет наша нынешняя идентичность, структура социальных возможностей - в том виде, в каком мы ее воспринимаем, когда мы трезвы, - не оставляет нам шанса пробрести другую. Сокращение горизонта в восприятии пьяного, однако, изменяет структуру возможностей и приводит к поступкам, которые его трезвое Я сочло бы проигрышной стратегией - пьяное хвастовство или переоценка своих физических сил могут служить двумя подходящими примерами. Эти изменения в выборе стратегий часто приводят к фатальным ошибкам, но их основной эффект заключается в демонстрации протрезвевшему Я той простой истины, что оно является чем-то за пределами собственного воображения. Пьянка порождает опыт не-идентичности» [Соколов, 2005: 94]. Для описания производства этого опыта не-идентичности ученый обращается к концепции Self, разработанной Ирвингом Гофманом [Гофман, 2000]. С точки зрения Гофмана, 
идентичность (данный термин отождествляется с Self) актора конструируется как им самим, так и окружающими его людьми и институтами. Идентичность это всегда результат сопроизводства. Разумеется, идентичность актора не является предзаданной и единственной, она может меняться в зависимости от того, в какой социальной ситуации находится актор, в каком он возрасте и так далее. Более того, довольно тяжело априорно судить, какие из социальных характеристик важны для самоопределения того или иного человека. Допустим, одна женщина может связывать свое «Я» с деторождением, а для другой опыт материнства вовсе не важен. В целом Соколов концентрируется на довольно узком аспекте употребления алкоголя - так называемых пьянках (участие в них свойственно в основном для подростков), в ходе которых участники целенаправленно пьют в чрезмерном количестве - такой опыт может быть описан как лиминальный [ван Геннеп, 1999] или ритуальный [Дюркгейм, 2018], смысл его преимущественно состоит в конструировании не повседневных ситуаций.

\section{Биографический метод изучения употребления спиртного}

Нам кажется перспективным исследовать, как опыт употребления алкоголя может влиять на конструирование идентичности актора. Разумно предположить, что для решения этой задачи необходимо глубинное биографическое интервью, поскольку только с его помощью можно проследить, как алкоголь в разные периоды жизни влиял на практики и самоопределение актора. Большинство исследований употребления алкоголя базируются на анализе количественных данных, что само по себе, разумеется, не является недостатком, однако такой тип данных не позволяет посмотреть на распитие спиртного именно как на практику (во многом имеющую собственную специфику в случае каждого отдельно взятого актора), связанную с конструированием собственного «Я». Зачастую исследования, основанные на количественной методологии, имеют своей целью отслеживание динамики употребления алкоголя в конкретном обществе. Так, считается, что в 1990-е годы в России спиртное пили в намного большем количестве, чем в настоящее время. Основная причина такого положения вещей связывается с тяжелой экономической ситуацией, которая имела место в стране в те годы, и низком качестве алкогольной продукции (впрочем, даже в рамках подобных исследований отмечается, что смертность от алкоголя не всегда коррелирует с уровнем жизни) [Nemtsov, 2002]. Мы не собираемся оспаривать эти выводы, однако хотим указать на то, что подобного рода обобщения неминуемо оставляют в слепой зоне индивидуальные истории употребления алкоголя. Биографическое интервью (особенно в единственном экземпляре), напротив, не позволяет нам делать каких-либо существенных обобщений, однако дает возможность исследовать отдельно взятый нарратив, где проявляются различные тактики (или модели) употребления алкоголя, а также связи между этими тактиками и специфическими жизненными обстоятельствами, в которых оказывается актор. Не в малой степени выбор в пользу биографического метода был обусловлен и теоретической рамкой. Как будет 
показано ниже, мы опираемся на теорию практик, чей исследовательский фокус направлен на максимально детальное описание тех или иных практических аспектов социальной жизни актора. Говоря «практика употребления алкоголя», мы указываем на то, что для актора распитие алкоголя является не случайным эпизодом в его биографии, а феноменом, обладающим длительным временным измерением и в той или иной степени значимым для выстраивания его идентичности и организации повседневности.

Конечно, такое интервью следует брать у человека, имеющую богатую историю взаимодействия с алкоголем. Также необходимо отметить, что употребление алкоголя - довольно сенситивная тема. Люди нередко скрывают факты употребления алкоголя или преуменьшают количество выпитого, боясь быть стигматизированными другими [Goffman, 1963]. Ввиду этого обстоятельства было принято решение интервьюировать близкую подругу автора на условиях анонимности. По результатам интервью можно утверждать, что такой ход оказался оправданным, так как нарратив содержит множество личных, драматичных, местами захватывающих историй об опыте употребления алкоголя, что вряд ли было бы возможно при разговоре с малознакомым или вовсе незнакомым человеком ${ }^{1}$. В процессе анализа нарратива мы постарались избегать каких-либо оценочных суждений, хотя порой это было непросто в виду того, что автор сам имеет опыт распития алкоголя, в том числе с информанткой. Все имена и места были изменены по просьбе информантки.

В начале анализа приведем краткую биографическую справку об информантке. Девушку зовут Маша, ей 23 года, она работает в рекламном агентстве, имеет степень бакалавра по специальности «психология», на данный момент проживает в Москве (снимает квартиру), родилась в Санкт-Петербурге, где и проживала до поступления в университет в Москве. Выросла в полной семье, имеет старшего брата, у семьи значительный материальный достаток (дорогая машина, квартира в центре Санкт-Петербурга).

\section{Три этапа употребления: от «игры» к «режимам вовлеченности» ${ }^{2}$}

В нарративе Маши прослеживается три этапа употребления алкоголя: подростковый (время проживания в Санкт-Петербурге и обучения в школе), студенческие годы (время проживания в Москве и обучения в вузе) и поствузовское время. Опишем каждый из этапов подробнее.

1 Отдельно следует упомянуть о том, что речевой стиль, используемый информанткой в данном интервью (в данном случае мы имеем в виду в основном обсценную лексику), представляет собой ее привычный язык общения с близкими людьми (одним из таких является автор текста), однако не стоит полагать, что такая форма выражения себя реализуется информанткой в иных разговорных ситуациях.

2 Здесь важно отметить, что мы, разумеется, описываем эти этапы относительно кратко, упуская из зоны внимания многие аспекты: например, мы отказались от детального описания повседневных практик употребления, сосредоточив внимание на наиболее запоминающихся для информантки эпизодах употребления, различиях между разными этапами употребления, «поворотных» моментах в жизни, связанных с состоянием опьянения, а также на ее рефлексии касательно алкоголизма. Более детальное обсуждение рутинизированных практик питья заслуживает отдельного исследования. 
Подростковый период. Как признается Маша, однажды мама сказала ей: «Маша, ты не могла не пить и не бухать, как свинота, потому что в два года, когда у тебя резались зубы, ты обмакивала соску в домашний коньяк» (в данном случае слово «свинота» является частью нарратива самой информантки, а не оригинальным выражением, использованным ее матерью). Таким образом, Маша указывает на то, что тяга к алкоголю в ее случае имела практически врожденный характер. При этом в семье информантки отношение к алкоголю было достаточно либеральным (но алкоголиков ${ }^{1}$ никогда не было). Родители Маши разрешали ей выпивать где-то с 16 лет вместе с семьей. Информантка говорит:

«Моя семья все время исповедовала прикол, что типа лучше с нами ченить нормальное, чем черте с кем, ну, давай здесь подставим: мускателем на какой-нибудь е ${ }^{* *}$ ной набережной».

Это вовсе не значит, что Маша не пила до 16. Первый опыт сильного опьянения она датирует возрастом 14 лет. При этом информантка указывает на то, что в школьные годы главной целью было вовсе не опьянение само по себе. Маша говорит, что прежде всего в алкоголе привлекала его запретность:

«В детстве и в подростковом возрасте всегда был свой шарм, потому что ты можешь быть пойманным, а тебе нужно как-то вырубать алкоголь, если у тебя, как у меня, нет склада домашнего вина, хотя иногда мой склад тоже пустел. Тебе нужно как-то его доставать, с кем-то договариваться, магазин у суда ведь потом закрыли ${ }^{2}$. И-и-и опять же - ты находишься под контролем родителей».

Основная ставка распития - поймают или не поймают родители. При этом Маша утверждает, что даже когда ее «ловили» в состоянии сильного опьянения, родители не вводили никаких строгих санкций. Грубо говоря, игра в «сокрытие опьянения» была своего рода самоцелью, никаких серьезных ставок в этой игре не было. Примечательно, что весь свой тогдашний опыт распития информантка делит именно на две категории: «поймали или нет». Первый расценивается как преимущественно неудачный, а второй - как некое достижение. При этом в части нарратива, относящегося к школьному

1 Проблема заключается в том, что «алкоголик» и «алкоголизм» являются крайне сложными для определения понятиями. В зависимости от различных обстоятельств (к примеру, собственной меры потребления) различные люди могут по-разному понимать эти концепты. Например, Жиль Делез говорил, что «алкоголик - это тот, кто постоянно бросает пить» (как известно, французский философ был знаменит любовью к спиртному). Модель определения алкоголизма, разделяемая Машей, будет продемонстрирована ниже. Говоря о том, что никто из членов семьи Маши не был алкоголиком, мы исходим прежде всего из ее собственного определения ситуации (ничто не указывает на то, что логику рассуждения Маши можно подвергнуть серьезным сомнениям: ее родители ходят на работу, зарабатывают деньги, отец регулярно водит машину; как сказала сама Маша, она никогда не видела в сильном алкогольном опьянении свою мать, а отца - лишь несколько раз во время праздников).

2 В «магазине около суда» продавали алкоголь без паспорта. 
периоду, отсутствуют упоминания о похмелье (которого, вероятно, тогда не было, в других частях нарратива похмелье становится относительно важным сюжетом) или какая-либо рефлексия, касающаяся алкоголя, зависимости, социальных последствий распития и т.д. Главным и практически единственным сюжетом здесь является «игра» с родителями.

Cmуденческий период. Следующий этап употребления алкоголя Маша связывает с переездом в Москву и проживанием в общежитии. Избавившись от контроля со стороны родителя (который и до этого трудно было бы назвать строгим), информантка начинает пробовать крепкие напитки с новообретенными знакомыми. Этот период, на наш взгляд, может быть охарактеризован с помощью метафоры «исследования» или «режима открытий», предлагаемого Тевено ${ }^{1}$, который французский ученый описывает следующим образом: «Благом в этом режиме является возбуждение от новизны. Окружение в состоянии удивления обеспечивает любопытство, сохраняющееся в процессе открытий» [Тевено, 2018: 29]. Эта цитата практически синонимична тому, что говорит об этом времени Маша:

«Мы бухали просто как свиньи, но очень интеллигентно. То есть я до сих пор не понимаю, как мы могли там два раза в неделю бухать егермейстер и при этом не нищенствовать, если сейчас я вроде как и работаю, но хватает мне все равно на диск Родиона Газманова и бутылку водки "Беленькая". Вот. То есть началось какое-то такое... Знаешь, удар по разнообразию. Типа: а пробовала егермейстер? - Да нет, не пробовала. Ща попробую. - А самбуку во рту давай тебе подожгу? - А давай. А джин давай пuть? - А давай. А там... Ну, ты понял. Причем дело было не столько в том, чтобы напиться в говно, хотя порой это случалось, но это как бы не было самоцелью. Просто хотелось пожить вот такой, как бы сказать, чтобы не звучать слишком по-старчески... отвязной жизнью, что ли. Попробовать весь этот разный алкоголь, как что пьянит, что mебе подходит, чmо - нет...»

На этом же этапе своей жизни Маша знакомится со своей лучшей подругой. Алкоголь сыграл в этом знакомстве важную роль. Обе девушки были застенчивыми и, несмотря на то что жили на одном этаже в общежитии, даже не здоровались. Однако, каким-то образом оказавшись на одной «пьянке» (Маша не помнит, как точно это случилось) и выпив вместе, они почувствовали «тягу» друг к другу. Впрочем, информантка отмечает, что алкоголь, безусловно, помог им подружиться и стал важной частью их «дружеского быта», однако общение не связано исключительно с употреблением спиртного:

\footnotetext{
1 Мы не стали ассоциировать игровую стратегию с каким-либо режимом вовлеченности по Тевено в виду того, что игра не похожа ни на один из режимов, описываемых французским ученым. Попытка соотнести игру и какой-либо режим (или еще более глобально - обосновать необходимость игрового режима) кажется весьма перспективной теоретической задачей, однако она выходит за рамки этой преимущественно эмпирической работы.
} 
«Ну, так, собственно, за большим количеством рюмок я с Олей, к примеру, познакомилась, а потом уже начала очень близко с ней общаться. Мы же обе замкнутые были, жили на одном этаже и даже не здоровались. А потом она оказалась у меня в комнате в компании, мы бухали джинанас, эта сучка поставила мою любимую песню Арбениной, и я такая: ты что, $6^{* *}$ mь, серьезно, тебе тоже это нравится? И понеслось: катала ее в тележке, пили перед ментовкой коньяк из горла, в общем, ты понял... Но это не значит, что мы такие две конченые алкоголички и как встречаемся, то обязательно в соплю. Мы и в музеи ходим, на кониерты, в общем, живем культурной жизнью. Тем более, сейчас мы уже женщины в преклонном возрасте, можем взять себе по пять пив и еще чего-нибудь крепкого сверху, а в итоге выпиваем по пиву, максимум, по паре, смотрим "Беременна в 16" и ложимся сnать».

На этом же этапе Маша начинает стигматизировать (в том значении термина, которое ему придает Гофман) и классифицировать людей, основываясь на их отношении к алкоголю. Условно информантка выделяет три «типа» людей:

1. Пьющие так же, как она: «Оля пьет столько же. Плюс-минус ты, наверное. Еще Настя, Кирилл. Ну, во всяком случае мы как-то всегда на одной волне».

2. Пьющие в «другом режиме», но не осуждающие употребление Маши:

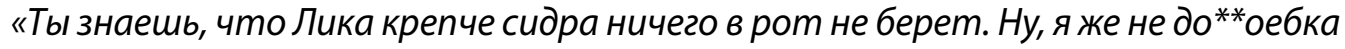
конченая, чтобы ей через силу заливать. Ну, не нравится - не пей. Она никогда не душнит. Вообще никаких проблем».

3. «Морализаторы»: «Слушай, ну, я, конечно, не хочу сказать, что если человек не пьет, то с ним нельзя нормально общаться. Просто иногда это создает некие проблемки. Вот, допустим, пошла я на свидание с парнем, вроде он нормальный такой, и я решила не танцевать эти сочиальные танцы, типа я не пью, мне там сок яблочный, не, я взяла себе два джин-тоника. Он так на меня посмотрел и говорит: ДВА? ДЖИН-ТОНИКА? Типа осуждающе. Ну, я такая: может, со мной что-то и не так, но с тобой тем более. Иди на х*й со своим морализаторством».

Как будет показано ниже, порой Маше вовсе не чужда рефлексия по поводу количества выпиваемого ею алкоголя, однако она категорически маркирует как «непригодных к общению людей» тех, кто пытается указать ей на чрезмерное выпивание. Рефлексия и «осуждение» оказываются исключительно ее личными прерогативами (возможно, было бы интересно порассуждать о том, какой была бы позиция Маши, если бы она подверглась осуждению со стороны очень близких людей, однако такого никогда не происходило, во всяком случае в серьезной манере).

Настоящее время (жизнь в отдельной квартире). Настоящий период парадоксальным образом характеризуется как увеличением рефлексии по поводу употребления, так и (возможным) ростом количества выпиваемого алкоголя. Маша говорит: 
«Когда я стала жить одна, то, разумеется, я стала намного меньше видеться с людьми, работа же практически вся на дистанционке, из-за ковида вообще пи**ец кромешный был, никуда не выйти, все разговоры только по зуму. И выпить бутылку вина, пока с кем-то по зуму nи**uшь, - это еще хорошо... Обычно каждый вечер в этом одиночестве, и без вина как-то бывает грустно... Раньше бывало такое, что нае ${ }^{* *}$ шься (напьешься. - Прим. автора) пару раз в неделю джина, и как-то в остальные дни не хочется пить. А сейчас как-то, наверное, чаще это стало происходить, но в меньших количествах за раз. За раз выпиваешь меньше, но пьешь каждый день почти. То есть возможно, что сейчас я пью больше, хотя, может, и нет. И иногда от этого, конечно, как-то не по себе, я бы даже сказала страшно, особенно когда засыпаешь одна в своей двуспальной кровати с пустой бутылкой рядом... А с другой - наутро спокойно встаешь, живешь эту жизнь, и страха нет, как пела Арбенина, то есть, думаю, это такая ситуативная штука, не связанная напрямую с алкоголем».

Здесь следует обратить внимание на пару моментов:

1. С одной стороны, Маша указывает на то, что возможный рост количества выпиваемого связан с внешними обстоятельствами (вынужденная изоляция из-за ковида и дистанционной работы; одиночество; нам кажется неслучайным подчеркивание информанткой того факта, что кровать у нее двуспальная, а спать в ней приходится одной, или, фигурально выражаясь, «с бутылкой»). Однако в другом месте нарратива она, скорее, опровергает такую связь:

«Говорят, типа алкоголь связан с жизненными обстоятельствами. Ну, разумеется, если человека абсолютно изолировать от спиртного, он не будет пить. Это можно считать связью? А так, есть парень, нет парня, есть дело, нет дела, есть кто-то рядом, нет кого-то рядом... Ситуации меняются. Одно неизменно - ты все равно выпиваешь. Просто по-разному».

Таким образом, в зависимости от обстоятельств могут меняться скорее «тактики» употребления (что, с кем и в каком количестве пить), но сам алкоголь остается своего рода константой.

2. Проблематика страха, обозначенная в приведенной выше цитате, в процессе интервью возникала не раз, к примеру:

«Жить без алкоголя? Наверное, да, но зачем? Представь, что у тебя нет руки. Сможешь ли ты жить? Да. Но вряд ли это будет круто. Да, для меня это важная часть жизни, в смысле пить. Мне просто нравится. Tyт нет ничего больше, но и не меньше этого. Иногда мне страшно, но мне страшно по многим поводам. И я пью не потому, что мне страшно. И страшно мне не всегда, потому что я пью. Но вообще, знаешь, рассказывая тебе 
все это, даже про дикий кринж, я как-то в основном испытывала радость. Все-таки это очень пи **атая часть моей жизни. Возможно, когда-то мне надоест пить и я откажусь от этого. Я не говорю, что это невозможно».

В этом коротком отрывке информантка совершает несколько интересных риторических ходов. Во-первых, подчеркивает, что поводов для страха много, так что даже если употребление является одним из них, то оно становится рядоположным другим условным проблемам. Грубо говоря, таким образом происходит отказ от «демонизации» алкоголя и связывания всех жизненных трудностей исключительно с его употреблением. Во-вторых, Маша эксплицитно указывает на то, что не пытается с помощью алкоголя развеять какиелибо страхи. В данный момент мотивация к употреблению лежит в плоскости удовольствия, причем это самое удовольствие тщательным образом оберегается от рефлексии, от постановки под сомнение (об этом еще будет сказано ниже). В-третьих, информантка в конечном итоге оценивает весь свой опыт употребления как позитивный, то есть все те издержки, которые она понесла в связи с этим, калькулируются как не слишком значительные.

Маша считает, что серьезных проблем с алкоголем до настоящего времени у нее не было (кроме неприятных похмелий, впрочем, тут сразу же необходимо обратить внимание на то, что в процессе интервью Маша до задавания эксплицитного вопроса о влиянии алкоголя на ее здоровье никогда не затрагивала данную проблематику, а ответ был следующим: «Ну, анализы периодически сдаю какие-то, все ок, в пределах нормы, никак, пожалуй, не повлиял... А думать о том, что где-то там аукнется, да нахер, может, завтра машина собьет и за просто так сдохнешь»). Не так давно, однако, имел место инцидент, который Маша расценивает как неприятный:

«Недавно я пила со своими друзьями, которые как бы типа пара. Не супер прям близкие друзья, но и не далекие знакомые. И я тогда довольно много выпила, и мы поехали по домам на такси, и я этого парня начала как-то немного трогать. Мы сидели с ним на заднем сидении, уже не помню, почему так вышло, а его девушка на первом. Не могу сказать, что особо помню тот эпизод, но все, кажется, понимали, что происходит. То есть его девушка это видела. Но ничего не сказала. Но, знаешь, на следующее утро тоже ничего критического не было. Я не извинялась, они никаких претензий не предъявляли. Мы до сих пор хорошо общаемся, но все-таки как-то неприятно было. Потому что это не слишком классная ситуачия. Но потрогать его и без алкоголя как бы, наверное, хотелось, поэтому алкоголь тут не суть вопроса».

В этом эпизоде интересно то, что алкоголь выступает важным действующим лицом, как и при знакомстве с Олей (только если в первом случае его роль оценивалась как положительная, то здесь, скорее, как отрицательная), но в обоих случаях его роль оценивается Машей в качестве побочной. Это довольно характерно для всего нарратива в целом. Информантка никогда 
не отрицает значимости алкоголя в своей жизни, порой даже культивируя это значение, однако она наотрез отказывается наделять его какой-либо серьезной каузальной силой в собственной жизни («с Олей мы просто друг другу подходим, просто в какой-то момент эта пьянка нас подтолкнула», «слушай, ну, я очки дорогие от солнца пр ${ }^{* *}$ ала, когда пьяная была, но ты сам знаешь, что я такая растеряша, что рано или поздно это случилось бы»). Таким образом, алкоголь занимает очень трудную для описания и концептуализации позицию, он как бы везде и нигде одновременно.

В данный момент Маша уже не рассматривает употребление алкоголя как своего рода исследование, что было актуально в период жизни в общежитии. Сейчас отношения информантки с алкоголем напоминают, скорее, «режим близости» по Тевено, в котором практика взаимодействия с вещами покидает пределы рефлексивного поля, становится настолько эмоционально значимой, необходимой, а с другой стороны - привычной, что говорение о ней оказывается затруднительным (порой тяжело сказать, почему мы любим очень близкого человека, даже несмотря на его недостатки) [Thévenot, 2007]. Маша говорит:

«Слушай, я действительно не задаюсь какими-то вопросами по поводу того, что это для меня значит. Понимаю, что значит многое, но тут нет значения как такового. Я просто пью. Я бы сделала упор на это слово "просто". Иногда думаешь, но чаще - нет. Я могу вот привести тебе как бы какие-то причины, начинающиеся с "потому что....", но это все неполно будет и неточно. Привычка? Пожалуй. Но не как курение. То есть это не физическое что-то, наверное. Вернее, не вполне физическое, больше эмоциональное».

В интерпретации Маши алкоголь не сводится к своим функциям, хотя наличие таковых и не отрицается (это напоминает онтологическую позицию Грэма Хармана, согласно которой «объект», в данном случае - алкоголь, не может быть исчерпывающим образом описан через то, что он «делает» [Харман, 2018]; эта позиция противоречит позиции Латура, которая формулируется ровно противоположным образом: вещь - это то, что она может совершить [Латур, 2014]. Здесь уместно вспомнить акторно-сетевое биографическое исследование формирования привязанности к алкоголю у девушки-подростка [Demant, 2009], однако мы считаем его сомнительным в силу того обстоятельства, что автор, стремясь наделить объекты агентностью (довольно вульгарное прочтение Латура), сводит формирование тяги к алкоголю преимущественно к внешним, далеко не очевидным с точки зрения самого информанта обстоятельствам. Чем старше становится Маша, тем больше употребление алкоголя уходит в сферу необсуждаемого, само собой разумеющегося, при этом количество выпиваемого алкоголя, может быть, и увеличивается (здесь невозможно сказать точно).

На этом этапе интерпретации следует быть очень аккуратным. Как мы указывали в начале текста, нередко социологи при изучении употребления 
алкоголя как социального феномена тяготеют к постановке диагнозов и вынесению оценочных суждений. Мы полагаем, что это не входит в задачи ученых. Возможно, после прочтения предыдущего абзаца у читателя возникнет впечатление, что у Маши начинает формироваться (или уже сформирована) алкогольная зависимость, сулящая ей серьезные проблемы в жизни. Однако здесь важно указать на два обстоятельства.

1. Сама Маша категорически отрицает то, что является алкоголиком:

«Ну, знаешь, как-то Хрусталев в интервью этой, как ее, Шихман, сказал, что если она выпивает каждый вечер по бокалу вина, то она алкоголичка.

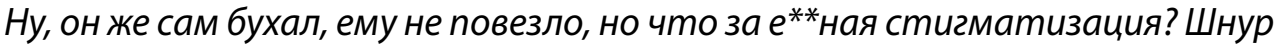
еще сказал, что есть статистика умерших от алкоголя, но где статистика выживиих? По-моему, зависимость - это когда все мысли только

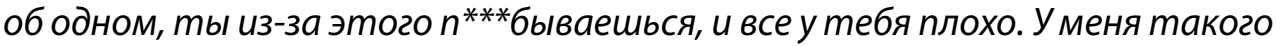
точно нет. Прям точно. Были косяки, но не тотальные. Я всегда выполняю свою работу, хорошо училась. У меня, может быть, высокий уровень потребления. Но это другое. Как в том меме: вы не понимаете, это другое».

В рамках данной работы мы не хотели бы занимать позицию так называемой просветительской социологии, полагающей акторов недостаточно компетентными, чтобы трезво (пускай это слово может прозвучать как каламбур в контексте исследуемой проблематики) оценить собственные действия и заменяющей их объяснения собственными концепциями, эпистемологические импликации которых могут полностью противоречить точке зрения акторов. Поэтому мы не считаем целесообразным говорить об «алкоголизме» Маши или вообще как-либо оценивать ее нарратив (насколько это возможно).

2. Интервью было выстроено вокруг алкогольной тематики, поскольку именно она в данном случае представляла исследовательский интерес. Ввиду этого обстоятельства может возникнуть впечатление, что вся жизнь Маши складывается из употребления алкоголя, но, разумеется, это противоречит действительности. Избежать этого «однобокого» раскрытия информанта было бы возможно с помощью нарративизации иных аспектов жизни девушки (любовные отношения, друзья, учеба, работа, увлечение вязанием), однако мы прекрасно отдавали себе отчет в том, что все эти значимые темы не могут быть адекватным образом представлены в рамках одного текста. Поэтому данное «упрощение» Маши представляется неизбежным, и мы как исследователи несем за него полную ответственность.

\section{Четыре концептуализации алкоголя, предлагаемые информанткой}

В процессе интервью Маша приводила четыре концептуализации алкоголя: демон, великая сила, социальная смазка, оправдание. Раскроем каждую из них.

1. Демон-алкоголь. Маша говорит: 
«Ну, когда-то я писала курсовую про алкоголь с одним моим другом до**оебом, и у нас был научник. И он чо-то там говорил про демона алкоголя, но вообще это же достаточно поп-культурная история. Демоналкоголь. Зеленый змий. Искушение. И все такое. Взять хотя бы эти все советские плакаты, где алкоголь нарисован таким достаточно чертикообразным образом. То есть один раз попробовал, и все - пи**ец. Потом просыпаешься без штанов на Красной площади. Это не из моего опыта».

Информантка не отрицает, что алкоголь связан с определенного рода рисками, однако она отвергает излишнюю демонизацию алкоголя, поскольку для нее такой подход приводит к неизбежно одностороннему и очевидно негативному дискурсу о спиртном. Опыт информантки содержит немало приятных воспоминаний о распитии, и ей, очевидно, не близка концепция демонизации алкоголя.

2. Великая сила. В этой концептуализации прослеживается указание на амбивалентные свойства алкоголя, и такая модель мышления куда ближе Маше, чем предыдущая:

«Ну, знаешь, алкоголь - это же великая сила, с которой приходит огромная ответственность. То есть, б*я, алкоголь открывает одни двери, но может закрыть другие».

Информантка считает, что «позитивная» сторона этой силы заключается в возможности устанавливать социальные контакты (о чем подробнее в третьем пункте) и «познавать» себя с недоступных в трезвом состоянии сторон. Например, Маша вспоминает, что в состоянии опьянения ей удалось написать эссе по одному из университетских курсов на максимальный балл. Это стало для нее неожиданностью, поскольку тот курс всегда вызывал у нее сложности; конечно, в данном случае практически невозможно оценить влияние алкоголя на итоговый результат, однако если сама информантка связывает успех именно с употреблением спиртного, то нам следует указать на это. «Негативная» сторона силы связывается Машей с чрезмерной эмоциональностью и «верой в себя»:

«Знаешь, когда ты сильно пьян, ты можешь буквально все сказать, что думаешь, и как будто тебе за это ничего не будет, ну, типа, ты настолько уверываешь в себя, свою правоту, чистоту взгляда и прочее, что буквально строишь себе проблемы на пустом месте. Tuna говоришь там кому-то "иди в жопу", а потом понимаешь, что сказать-то, может, и хотелось, но абсолютно не стоило».

3. Социальная смазка. Это определение является следствием второго, поскольку подчеркивает силу алкоголя в установлении социальных контактов. Маша говорит: 
«Я как-то ездила на летнюю школу. Там были шведы, более-менее поанглийски я могла, и они могли, но первые два дня там ни бе, ни ме, ни аниме, как говорится. А я вот, $6^{* *}$ ть, как знала: с собой прихватила «чивас» пятнадиатилетний. Подхожу к ним вечером с бутылкой и говорю: guуs, I am going to знакомиться. Шведы бутылку увидели, заулыбались. И так, собственно, мы и подружились. С некоторыми до сих пор переписываюсь. A вот подруга моя Даша не пьет. И ни с кем она тогда и не познакомилась. Так что вот так. А могла бы себе какого-нибудь шведа отхватить».

Информантка утверждает, что алкоголь помогает сделать первый шаг при установлении контакта с другими людьми. Это, впрочем, вовсе не означает, что общение возможно исключительно при помощи алкоголя.

4. Алкоголь как оправдание.

«Ооо, это мое самое любимое. Знаешь этот момент, когда очень хочется что-то сделать, но не хочется нести за это ответственность? Ну, переспал с кем-то не тем, станцевал там где-то на столе, ну, это я образно, преподу на выпускном сказал все, что о нем думаешь, и такой потом: ээм, извините-простите, была пьяна, ничего не помню. Бес попутал, ахаха! Причем в большинстве таких случаев я даже не перед ними оправдываюсь, а перед собой. На самом деле мне $n^{* *}$ й, что там они обо мне подумают. Понятно, что это какие-то такие out of the blue cumуаиии. С близкими людьми так грубо я эту карту не разыгрываю. Там если что-то такое, я правда извиняюсь».

Здесь интересно, что «пьяное я» условно обслуживает интересы «трезвого я», при этом они никогда не сливаются в одну идентичность. Также следует обратить внимание на то, что такая тактика «раздвоения» личности используется Машей в основном для достижения сиюминутных целей, связанных с общением не с близкими людьми. То, что Соколов называет «не-идентичностью», здесь приобретает скорее форму альтернативной идентичности, которая актуализируется ad hoc.

\section{Заключение}

Завершить нашу интерпретацию мы постараемся небольшим резюме. В семье Маши существовало либеральное отношение к употреблению алкоголя, что позволило девушке начать пить в относительно раннем возрасте (около 14 лет). Однако здесь не стоит с уверенностью говорить, что именно это стало причиной ее тяги к алкоголю. Далеко не каждый человек будет пить в юном возрасте, если ему это позволить, как и далеко не каждый, имеющий склонность к употреблению алкоголя, откажется от употребления, если его ограничить (скорее всего, такой человек будет занят поиском лазеек 
в ограничениях). Мы как социологи едва ли можем сказать, откуда взялась эта тяга, но способны проследить ее социальное бытование и видоизменение.

В начальный период девушка воспринимала употребление алкоголя как игру в «кошки-мышки» с родителями, впрочем, без серьезных ставок. В студенческие годы тяга приобрела форму исследования. Желание попробовать как можно больше и полное отсутствие контроля со стороны родителей, вероятно, привели к увеличению количества употребляемого алкоголя. В этот период информантка не рефлексировала о характере связи себя и алкоголя, зато ощущались его положительные эффекты: раскрепощение, открытие новых граней себя, знакомство с лучшей подругой. В настоящее время Маша пьет преимущественно алкогольные напитки одного вида (сложилась система преференций), нередко в одиночестве. На этом же этапе началась и рефлексия по поводу практики распития, однако такие размышления не привели ни к какому окончательному выводу или смене «тактики» употребления: алкоголь в этой рефлексии является действующим, но отнюдь не главным лицом в жизненных событиях Маши. Здесь следовало бы написать «to be continued...», что мы и сделали.

В заключении хотелось бы немного поговорить о методологических аспектах интервью. Автор текста и Маша являются близкими друзьями. С одной стороны, это способствовало откровенности разговора, с другой - автор может быть склонен к предвзятой интерпретации нарратива. Кроме того, алкогольные практики Маши и автора во многом сходны (хотя не идентичны), что могло склонять автора к романтизации и идеализации нарратива информантки - надеемся, что нам удалось в максимальной степени избежать данных соблазнов. Не лишним будет указать на то, что интервью проводилось по зуму. В процессе разговора Маша пила пиво (слово информантке: «Ну, раз говорим об алкоголе, то даже как-то странно будет пивка не расчехлить»). К концу разговора была выпита одна бутылка, что могло в той или иной степени повлиять на выстраивание нарратива информанткой (хотя вряд ли), но мы посчитали нецелесообразным отгораживать этот разговор от той формы социальности, в которой удобно существовать Маше. Автор от употребления алкоголя во время интервью воздержался (возможно, в силу неких этических причин, но, скорее, ввиду его отсутствия под рукой).

\section{Литература}

ван Геннеп А. Обряды перехода. М.: Восточная литература РАН, 1999.

Гофман И. Представление себя другим в повседневной жизни. М.: Канон-Пресс-Ц, Кучково поле, 2000.

Дюркгейм Э. Элементарные формы религиозной жизни: тотемическая система в Австралии. М.: Элементарные формы, 2018.

Латур Б. Пересборка социального: введение в акторно-сетевую теорию. М.: Изд. дом ВШЭ, 2014.

Соколов М. Пьянка: Исследование социального производства опыта не-идентичности // Беспредельная социология. Сборник эссе к 60-летию Воронкова В. / Под ред. О. Паченкова, М. Соколова, Е. Чикадзе. СПб.: ЦНСИ, 2005. С. 83-97. 
Тевено Л. Жизнь как испытание // Неприкосновенный запас. 2018. № 119. С. 3-29.

Харман Г. Имматериализм. Объекты и социальная теория. М.: Институт Гайдара, 2018.

Demant J. When Alcohol Acts: An Actor-Network Approach to Teenagers, Alcohol and Parties // Body \& Society. 2009. Vol. 15. № 1. P. 25-46. DOI: https://doi.org/10.1177/1357034x08100145

Goffman E. Stigma: Notes on the Management of Spoiled Identity. N.Y.: Prentice-Hall, 1963.

Heath D. Anthropology and Alcohol Studies: Current Issues // Annual Review of Anthropology. 1987. Vol. 16. № 1. P. 99-120. DOI: https://doi.org/10.1146/annurev.an.16.100187.000531

Mulford H., Miller D. An Index of Alcoholic Drinking Behavior Related to Meaning of Alcohol // Journal of Health and Social Behavior. 1961. Vol. 2. № 1. P. 26-41. DOI: https://doi.org/10.2307/2948860

Nemtsov A.V. Alcohol-Related Human Losses in Russia in the 1980s and 1990s // Addiction. 2002. Vol. 97. № 11. P. 1413-1425. DOI: https://doi.org/10.1046/j.1360-0443.2002.00262.x

Seeman M., Seeman A., Budros A. Powerlessness, Work and Community: A Longitudinal Study of Alienation and Alcohol Use // Journal of Health and Social Behavior. 1988. Vol. 29. № 3. P. 187-198. DOI: https://doi.org/10.2307/2137031

Thévenot $L$. The Plurality of Cognitive Formats and Engagements: Moving between the Familiar and the Public // European Journal of Social Theory. 2007. Vol. 10. № 3. P. 409-423. DOI: https:// doi.org/10.1177/1368431007080703

\section{Сведения об авторе:}

Котельников Максим Павлович - студент магистерской программы «Комплексный социальный анализ», Национальный исследовательский университет «Высшая школа экономики», Москва, Россия. E-mail: don.kotelnikov@yandex.ru. ORCID ID: 0000-0003-3946-6636.

\section{Alcohol and the Identity-Building Experience: The Biographical Interview}

DOI: 10.19181/inter.2021.13.3.6

\section{Maxim P. Kotelnikov HSE University, Moscow, Russia \\ E-mail:don.kotelnikov@yandex.ru}

Within the framework of this paper, the author examines individual drinking "strategies" and their relationship with the social context. To accomplish this task, the author turns to the concept of 'modes of engagement' by Laurent Thévenot. On the base of an in-depth interview, the author identifies three stages of alcohol consumption that the informant went through: 1) adolescence, which can be described as a "game", the essence of which boils down to hiding the fact of drinking alcohol from the parents; 2 ) the student period (life in a dormitory), when the strategy of consumption can be described as the 'discovery mode' according to Thévenot, a distinctive feature of which is the search for something new; 3 ) the present (living alone), which is characterized by a non-reflective routine use of alcohol. Such a 
strategy is brought in accordance with Thévenot's "mode of intimacy", which is characterized by an increase in the importance of an object (in this case, alcohol); however, at the same time, the actor loses the opportunity to reflect on his relationship with the object, due to the fact that it becomes a part of his "unquestioned" everyday life. The article also examines the models of conceptualization of alcohol and alcoholism, used by the informant herself.

Keywords: modes of engagement; alcohol; alcoholism; stigma; biography; game

\section{References}

Demant J. (2009) When Alcohol Acts: An Actor-Network Approach to Teenagers, Alcohol and Parties. Body \& Society. Vol. 15. No. 1. P. 25-46. DOI: https://doi.org/10.1177/1357034x08100145

Durkheim E. (2018) Elementarnye formy religioznoj zhizni: totemicheskaya sistema $v$ Avstralii [Elementary Forms of Religious Life]. Moscow: Elementarnye formy. (In Russ.)

Goffman E. (1963) Stigma: Notes on the Management of Spoiled Identity. N.Y.: Prentice-Hall.

Gofman E. (2000) Predstavlenie sebya drugim v povsednevnoj zhizni [The Presentation of Self in Everyday Life]. Moscow: Kanon-Press-C, Kuchkovo pole. (In Russ.)

Harman G. (2018) Immaterializm. Ob'ekty i social'naya teoriya [Immaterialism: Objects and Social Theory]. Moscow: Institut Gajdara. (In Russ.)

Heath D. (1987) Anthropology and Alcohol Studies: Current Issues. Annual Review of Anthropology. Vol. 16. No. 1. P. 99-120. DOI: https://doi.org/10.1146/annurev.an.16.100187.000531

Latur B. (2014) Peresborka social'nogo: vvedenie v aktorno-setevuyu teoriyu [Reassembling the Social: An Introduction to Actor-Network-Theory]. Moscow: Izd. dom VShE. (In Russ.)

Mulford H., Miller D. (1961) An Index of Alcoholic Drinking Behavior Related to Meaning of Alcohol. Journal of Health and Social Behavior. Vol. 2. No. 1. P. 26-41. DOI: https://doi.org/10.2307/2948860 Nemtsov A.V. (2002) Alcohol-Related Human Losses in Russia in the 1980s and 1990s. Addiction. Vol. 97. No. 11. P. 1413-1425. DOI: https://doi.org/10.1046/j.1360-0443.2002.00262.x

Seeman M., Seeman A., Budros A. (1988) Powerlessness, Work and Community: A Longitudinal Study of Alienation and Alcohol Use. Journal of Health and Social Behavior. Vol. 29. No. 3. P. 187-198. DOI: https://doi.org/10.2307/2137031

Sokolov M.M. (2005) P'yanka: Issledovanie social'nogo proizvodstva opyta ne-identichnosti [A Booze: Research into the Social Production of Non-Identity Experience]. In: Pachenkov O., Sokolov M., Chikadze E. (eds.) Bespredel'naya sociologiya. Sbornik esse k 60-letiyu Voronkova V. [Boundless Sociology. Collection of Essays for the 60th Anniversary of Voronkov V.]. St. Petersburg: CNSI. P. 83-97. (In Russ.)

Teveno L. (2018) Zhizn' kak ispytanie [Life as a Challenge]. Neprikosnovennyj zapas [Untouchable Reserve]. No. 119. P. 3-29. (In Russ.)

Thévenot L. (2007) The Plurality of Cognitive Formats and Engagements: Moving between the Familiar and the Public. European Journal of Social Theory. Vol. 10. No. 3. P. 409-423. DOI: https:// doi.org/10.1177/1368431007080703

van Gennep A. (1999) Obryady perekhoda [The Rites of Passage]. Moscow: Vostochnaya literatura RAN. (In Russ.)

\section{Author bio:}

Max P. Kotelnikov - Master's Student, HSE University, Moscow, Russia. E-mail: don.kotelnikov@yandex.ru. ORCID ID: 0000-0003-3946-6636. 